\title{
Retraction Note to: Contrasting Embodied Cognition with Standard Cognitive Science: A Perspective on Mental Representation
}

\author{
Pankaj Singh
}

Published online: 4 September 2020

(C) ICPR 2020

\section{Retraction to: Journal of Indian Council of Philosophical Research (2019) 36:125-149 https://doi.org/10.1007/s40961-018-0159-5}

The Editor-in-Chief has retracted this article [1] because parts of the text were duplicated from publications by different authors [2, 3]. Author Pankaj Singh agrees to this retraction.

\section{References}

1. Singh, P. (2019). Contrasting embodied cognition with standard cognitive science: A perspective on mental representation. Journal of Indian Council of Philosophical Research, 36, 125-149. https:// doi.org/10.1007/s40961-018-0159-5.

2. Shapiro, L. (2011). Embodied cognition. London: Routledge.

3. The Cambridge Handbook of Situated Cognition. (2008). In P. Robbins \& M. Aydede (Eds.), The Cambridge handbook of situated cognition (Cambridge Handbooks in Psychology, pp. I-Ii). Cambridge: Cambridge University Press.

Publisher's Note Springer Nature remains neutral with regard to jurisdictional claims in published maps and institutional affiliations.

The original article can be found online at https://doi.org/10.1007/s40961-018-0159-5.

\section{Pankaj Singh}

pankajsingh.028@gmail.com; pankajsi@iitk.ac.in

1 Indian Institute of Technology, Kanpur, Room No. S 303, New RA Tower, Kanpur, India 